\title{
HANGING IN THERE: ZIMBABWEAN MIGRANT WORKERS IN JOHANNESBURG
}

\author{
Chipo HUNGWE 3
}

DOI: 10.35782/JCPP.2020.3.05

Abstract: With the worsening political and socio-economic climate of Zimbabwe, migration to South Africa continues unabated. Research has already proven that migration is a result of many push and pull factors. The prospect to improve one's life and that of one's kin remains a key motivation for migration. What needs to be clearly articulated, in so far as Zimbabwean migration to South Africa is concerned, is the level of economic stability of Zimbabwean workers within the South African job market. This is the aspect addressed in this article, which contends that most of the Zimbabwean migrant workers in Johannesburg, South Africa are employed in careerless and unstable jobs that are precarious. While precariousness exists everywhere, and in varying levels, I argue that the migrant status is a devalued identity that leads to exclusion from certain basic rights at work and worsens the situation for most unskilled and semi-skilled Zimbabweans. Zimbabwean workers possess certain characteristics that both create advantages and disadvantages for them as they interact with employers. Employers know this fully well and capitalise on these characteristics, especially the lack of documentation needed to work and stay in South Africa.

The precarious nature of Zimbabwean migrants is an outcome of a combination of various factors which are: a very strict migration legal framework, institutionalised xenophobia, capitalists whose interests are in lowering labour costs and thus go for cheap Zimbabwean labourers, desperate Zimbabwean workers who would accept anything offered because it is believed to be far much better than what they would receive 'back home' and a sending government (Zimbabwean) which does not seem to care enough about the situation of migrants who are mainly viewed negatively for having left the country in the first place. The precariousness of Zimbabwean migrants is both as much

${ }^{3}$ Associate Professor in the Department of Sociology, The Faculty of Social Sciences, Midlands State University, Gweru, Zimbabwe. Email: hungwec@staff.msu.ac.zw, blessedhungwe@gmail.com. Phone: $+263773747886 /+263-254-260404$ ext. 2015. A version of this paper was presented at the 2018 ILERA congress in Seoul, South Korea. The author would like to acknowledge comments received from that congress. 
a product as it is also a factor of a vicious cycle of precariousness. The intersection of the migrant status (whether documented or undocumented but even worse for the undocumented) with low educational qualifications (for most migrants studied), race (black), poverty and desperation creates barriers and constraints for most Zimbabwean migrants rendering their lives quite precarious.

Keywords: Employer; Labour; Migrant; Precarious; South Africa; Zimbabwean

\section{Introduction}

This study explains the situation of Zimbabwean migrants (both documented and undocumented) in the South African labour market showing the extent of their participation and the types of jobs that they participate in. It explains clearly the levels of earnings, conditions of work and how these Zimbabwean migrants feel about their work. In understanding the extent of participation of Zimbabwean migrants in the South African labour market the questions I attempt to answer are: How did they enter the labour market? What kinds of jobs do migrants have? Where do they work? With whom do they work? What are the relations like at work? What kind of contracts, benefits and protection do they have?

In answering these questions the paper exposes areas and varying levels of precariousness faced by Zimbabwean migrants in the South African labour market. Elsewhere I have argued, using the queuing theory that Zimbabwean migrants may be located lower down the labour queue because of various factors that employers consider. These may largely be connected to the immigration policies (Hungwe, 2014). This may leave most Zimbabweans with little choice than to take unattractive jobs on the market as they themselves may be located lower down the labour queue. Some have ventured into selfemployment precisely because of this queuing. Whichever option is available, Zimbabwean migrants in Johannesburg seem to be confronted with varying levels of precariousness in the South African labour market.

\section{Background}

\section{Reasons for migration}

At the global level, literature reveals that international migration is on the rise facilitated by processes of globalisation and transnationalism. While South-West migration has traditionally dominated, there is an increase in South-South migration (Castles, 2002; Castles and Miller, 2009; UNDESA, 2016). The number of international migrants defined as persons living in a country other than where they were born, reached 244 
million in 2015, an increase of 71 million or $41 \%$ compared to 2000 (UNDESA, 2016). The majority of migrants $(72 \%)$ were between $20-64$ years reflecting a close connection between migration and labour activity (ibid). Officially recorded remittances to developing countries amounted to $\$ 431.6$ billion.

The importance of a job and work in the socio-psychological and economic outlook of an individual cannot be overemphasised. We are who we are because of the jobs we do. An individual's identity is closely tied with their job. With a job comes status and issues of self-worth. Participation in the labour market is also deemed good for the economic wellbeing of an individual and their family. Most migrants leave their countries in search of better jobs and economic opportunities (Prada, 2013). Zimbabwean migrants are no different. Their migration has been deemed "survival migration" (Betts and Kaytaz, 2009) because of the economic motive to acquire work and survive.

Literature reveals that migrants always compare their situation in the destination country with that in the country of origin. Waldinger and Lichter (2003) state that immigrants operate with a dual frame of reference, judging conditions "here" by the standards "back home". As long as the comparison remains relevant, low status and indeed, disreputable work in an advanced capitalist economy like South Africa may not rate too badly. This seems to be the case for Zimbabwean migrants who evaluate the South African labour market as far much better than the Zimbabwean economy. That is why they leave. While the reasons for Zimbabwean migration to South Africa are a combination of the harsh economic environment and increasing political intolerance, Zimbabwean migration has largely been a result of economic pressure [high levels of unemployment, inflation and lack of access to basic necessities for survival] (Bolt, 2015; Crush and Tevera, 2010; Tevera and Zinyama, 2002). Because of these economic reasons, migrants seem desperate to take any kind of job available and thus become willing labourers who may not be choosy on the South African labour market.

\section{Employer interests}

Like any other developed economy, South Africa has experienced the growth of the service sector with some of the jobs requiring low levels of skill but with some level of interaction with customers. Most low end service sector jobs are characterised by low skill levels, minimum language proficiency, undesirable night or weekend shifts and typically offer limited or no advancement prospects (Sassen-Koob, 1985: 305). Such jobs may not be desirable to many, especially the natives of a country, leaving migrants to occupy them. Migrants may then eventually occupy positions that are generally looked down upon and are unwanted by the locals. However, in these interactive service jobs, employers want workers with a certain "right attitude". Employers do not simply want friendly employees who are able to keep a smile regardless of how unpleasant the customers or working conditions are, they also prefer "cooperative" to "combative" and 
deferential over rebellious employees. In other words, employers prefer a worker who knows his/her place (Waldinger and Lichter, 2003: 16). The migrant typifies this kind of worker by virtue of either being new to the market or if not new, is undocumented or incapacitated in some ways, to cause trouble with the employer.

Employers take advantage of lack of proper work documents in order to engage in work practices that are unacceptable to native born workers. According to Browning and Rodriguez (1985) employers may speed up the work pace and in some instances fail to provide workers with rest periods that other native/local workers receive. Employers may hire undocumented migrants at one level and then require them to do higher level work at no increase in pay (ibid). For those that try to resist, employers may threaten to report undocumented migrants to the immigration officials or police (Browning and Rodriguez, 1985). In South African farms, some farmers not only threaten deportation but actually employ undocumented workers who once their labour is no longer needed, are handed over to the police for deportation (Bloch, 2008; HRW, 2006; Dumba and Chirisa, 2010; Rutherford, 2010).

\section{The legal framework of Zimbabwean migration to South Africa}

Both Zimbabwe and South Africa belong to the Southern African Development Community (SADC) a regional body that functions to create and perpetuate socioeconomic and political cooperation among member states. The two countries have also signed the SADC protocol on the facilitation of movement of persons between and among countries of the SADC region. This Protocol facilitates the movement of SADC nationals without the requirement of a visa for up to 90 days of stay. Some Zimbabweans take advantage of this provision to enter South Africa and eventually do not come back to Zimbabwe upon the expiration of the 90 days. In fact the Immigration Authorities have of late, been reluctant to allow Zimbabweans to enter and stay in South Africa for more than 30 unless they have a work, business or corporate permit. As a result, some Zimbabwean and indeed SADC nationals find themselves with no right to stay and work in South Africa although the right to enter may have been granted.

Zimbabweans can and have entered South Africa using the provisions of the Immigration Act of 2002 amended in 2004 and the Immigration Regulations of 2005. Sections 34, 41, 42 and 49 provide for the arrest and deportation of illegal migrants either by the immigration officers or the police or both and detention for up to three months (90 days). In terms of section 41 of the Immigration Act of 2002, immigration and police officers have the power to request that individuals produce some form of identification on demand. The Immigration Act (section 41 subsection 1) provides that "[...] if on reasonable grounds such an immigration officer or police officer is not satisfied that such a person is entitled to be in the republic [...] such immigration 
officer or police officer may take such person into custody without a warrant [...]”. The Immigration Act has given state officials power to decide who enters and stays in South Africa and who does not. This has given rise to different forms of exclusions and inclusions and negotiations between the migrants and state employees such as Immigration officers, the police and soldiers, some of whom have benefited corruptly from such negotiations (Vigneswaran et al., 2010). This becomes quite critical especially in a society rocked by very high levels of institutionalised xenophobia.

Globally there is agreement on the rise of discrimination and xenophobia against migrants. These attitudes are sometimes deliberately fuelled by political leaders. This happens in both developed and developing countries (Borjas and Tienda, 1985). In South Africa, while there may be episodes of xenophobic attacks that get attention through the media (the latest having been in September 2019 which claimed the lives of about five foreigners [although the number is disputed] and damaged property of migrant shop owners), Zimbabweans report that xenophobia is an everyday experience. This is particularly the case as Zimbabweans try to access different government institutions such as schools, hospitals, the police and immigration offices and the labour market (Crush and Tawodzera, 2011; Dumba and Chirisa, 2010; Hungwe and Gelderblom, 2014). Migrants also perceive that their situation is exacerbated by the lack of interest in their welfare by their country of origin. This is particularly true for Zimbabwe where utterances by political leaders, especially the late President Robert Mugabe, labelled migrants as traitors or detractors of the ruling regime (McGregor, 2010).

\section{Conceptualising Zimbabwean migrants as the precariat}

The growing literature on new forms of work which create vulnerability and instability on the part of workers has called attention to the danger or precarity workers face in the global capitalist economy. This corpus of knowledge called attention to the movement away from the post-war settlement of the standard employment relationship to the new atypical, contingent forms of work which largely expose workers to precarity. Kalleberg (2013) creates a typology of good versus bad jobs on the basis of the vulnerabilities they create on workers. Because of the vulnerability and instability brought by these new forms of work, there have been calls for restoring the dignity of jobs, hence the Decent Work Agenda by the International Labour Organisation (ILO). The Decent Work Agenda is premised on the notion that we are humans first before we become workers (Peccoud, 2004). This means that work must not only be meaningful to the worker but must also be dignified and fulfilling.

The concept of precarious work is from the French term precarite which refers to vulnerability, instability and insecurity. It is the feeling of being devalued by business, 
and powerlessness due to the assault on unions and dealing with a shrinking welfare system (Kalleberg, 2009). The ILO (2011: 05) defines precarious work as:

"[...] work performed in the formal and informal economy and is characterized by variable levels and degrees of objective (legal status) and subjective (feeling) characteristics of uncertainty and insecurity. Although a precarious job can have many faces, it is usually defined by uncertainty as to the duration of employment, multiple possible employers or a disguised or ambiguous employment relationship, a lack of access to social protection and benefits usually associated with employment, low pay, and substantial legal and practical obstacles to joining a trade union and bargaining collectively".

From the 1970's, European workers became increasingly vulnerable to the labour market and began to organise around the concept of precarity as they faced living and working without stability or a safety net. This is said to have been a result of the following: the increase in spatial restructuring of work on a global scale (mobility of capital) and global price competition, technological advances which enable this spatial restructuring, union decline, deregulation of the economy by governments (neoliberalism), management attempts to achieve flexibility (which led to various types of restructuring and transformations in the nature of the employment relationship; e.g. layoffs and involuntary terminations becoming the norm. Figart and Warnecke (2013) define flexibilization as generally referring to shifts in production processes away from large integrated factory work sites, unionised workers and mass production of standardised consumer goods to spatially dispersed [global] production networks, increasingly casualised and informalized workers and small batch 'just in time' procurement and production), growth and expansion of the information based economy and the service sector which is organised around flexible production (Kalleberg, 2009).

The causes of precarious work are evaluated by the ILO as outcomes of an active and complicated interplay of factors mainly safeguarding capitalist interests while creating a group of vulnerable workers. Thus:

'The making of the 'precariat' is a multilevel process. It is an interaction between abuse of economic power, economic liberalization, global capital mobility, fierce lobbying against protective labour laws and a whole range of state policies guided by economic thinking that believes in the efficiency of free markets. It is this interconnectedness that creates the impression of inevitability, where each single measure looks like an adaptation and reaction to forces deemed beyond control of any actor. In this context, precarious employment is as much a consequence of increased competition as it is a powerful driver of increasing competition" (ILO, 2011: 18). 
While precariousness exists in different forms and degrees, there are groups that have been identified as more affected by precariousness than others. Such groups include the young, old, migrants, ethnic minorities and women (Tucker, 2002; Young, 2010; ILO 2011). Young (2010) posits that precariousness exists in a continuum from high precariousness to low precariousness, with high precariousness found in nonstandard/ atypical forms of work arrangements. In South Africa, migrants face many obstacles to standard work arrangements and thus end up in non-standard work arrangements. These have created limited space for survival rendering migrants' existences precarious (Crush et al., 2009; Standing, 2011). In its extreme form, precariousness creates "rightless" workers or "denizens" rather than citizens (Standing, 2011). Standing (2011) further warns that as the formal sector shrinks further and further, more people join the precariat which is deemed to be a growing class of frustrated, alienated workers engaged in meaningless jobs. Arguing from a Marxist perspective, Standing (2011) analyses this group as capable of causing social unrest in the future. This paper elaborates and discusses these views giving specific emphasis to the Zimbabwean migrant group in Johannesburg.

\section{Methods and Setting}

This research is a qualitative study of 58 migrants based in Johannesburg, South Africa. The material for this paper was originally gathered for a Doctoral research on survival strategies of Zimbabwean migrants in Johannesburg conducted between 2011 and 2013. Subsequent material has been gathered over time to augment the findings of this study. This paper presents views of Zimbabweans without those of their employers. The migrants in the study were sampled using snowballing based on initial contacts made with migrants in Kempton Park and Tembisa. Snowballing is a better method for hard to find populations where no known sampling frame exists (Browne, 2005). The weakness of the study could be the fact that only Zimbabweans were interviewed and thus the perceptions of their employers were not sought. However, it was the intention of the researcher to interview Zimbabweans only as the study sought to understand the perceptions of Zimbabwean migrants in the South African labour market. In-depth and semi structured interviews were conducted. It must be noted that the names indicated in the findings are pseudonyms created to protect the privacy of the research participants. Attempts to validate migrants' narratives were made through thick descriptions, verifications with other migrants and in some instances repeated interviews.

\section{Findings and Discussion}

Zimbabwean migrants were found in very diverse fields such as: administration, teaching, accounting, marketing, security, information technology, motor mechanics, engineering, transport, the church and the food service industry, however, some sectors 
were more receptive to Zimbabweans than others. These were the Zimbabwean dominated sectors. Zimbabweans rarely moved out of these sectors. These sectors were characterised by easy entry and easy exit. They were also characterised by poor conditions of service and wages with no migrant employee participation. Most migrants (69\%) earned less than R6000 (approximately USD \$600) per month with no other benefits available at work regardless of whether migrants were documented or not. The capitalist interests in migrant labour are exposed clearly in the discussion of migrants' perceptions regarding employer preference. Migrants perceived that, on average, employers preferred hiring Zimbabwean migrant labour because of the available opportunity to exploit these migrants and also because of their perceived better investment in human capital and positive attitudes towards work. However, there were few exceptions to this rule as would be revealed in the discussion.

The relations at work were mainly perceived as riddled with racial discrimination and xenophobia. These factors were some of the reasons for migrants' entry into selfemployment. Of much emphasis was the fact that successful self-employment hinged on the migrants' ability to acquire legal identity documentation which enabled the 'shedding off of the devalued Zimbabwean identity.

\section{Strategies of looking for a job}

The methods used by migrants to get a job were: standing at strategic points (such as traffic lights at road traffic intersections) carrying a placard or sign describing what one can do; going door by door in shops asking for employment; using agencies to send a curriculum vitae to prospective employers or having a relative referring the migrants or sometimes taking the migrant to the prospective employer. The most common methods among the unskilled migrants included standing at strategic points (especially those targeting the construction industry and odd jobs such as painting and plumbing) and moving door by door (for those targeting the retail and food industry). The whole process of looking for a job is called ukumaketha (literally meaning marketing or advertising). Van Nieuwenhuyze (2009) calls this 'the asking strategy' where migrants move around looking for vacancies. Vivienne explains how she got a job as a waitress:

"I found the job on my own... I went shop by shop, door by door looking for a job (and) getting rejected... but I kept my faith never getting discouraged".

This asking strategy can be stressful as an individual is never guaranteed of good reception where s/he goes looking for jobs. It can also be a process that is potentially embarrassing and degrading especially for the more educated migrants who might have had better expectations and who most likely would have left higher status jobs in Zimbabwe. 
Here is another description of ukumaketha by Bernard who got odd jobs while standing by the traffic lights:

"You would stand by a robot (traffic light) and signal with a finger that you are looking for a job and you are alone. The white man would stop and you quickly jump into his truck. There was competition so you needed to be the first to jump into the truck. You would then spend the whole day painting or plumbing or doing whatever was required by the employer... But you needed to be careful in raising the proper finger and signal properly otherwise using the wrong finger would be an insult that elicits anger from the prospective employer".

For most migrants this process of 'marketing' was largely guided by seasoned migrants (relatives and friends) who would go with the new migrant to the traffic light, so it was less stressful. However, for some individuals who had no relatives to induct them (like Bernard who was unfortunate in that his brother who had invited him got very sick and had to be ferried back to Zimbabwe just three days after Bernard's arrival) they had to use ingenuity to survive although other friends would help in one way or the other.

\section{Participation in the labour market}

Of the 33 males, 21 (64\%) were employed in the formal sector, ten (30\%) were selfemployed and two $(6 \%)$ were employed in the informal sector. There were no unemployed males. Male migrants engaged in all kinds of jobs in order to earn a living. Among the twenty five females nine (36\%) were employed in the formal sector while twelve $(48 \%)$ worked in the informal sector and some were self-employed. Females worked as domestic workers/ housemaids while others were in retail and food outlets, teaching and administration. There were four (16\%) female migrants who were unemployed. Women seemed to have fewer opportunities than men when it came to working in the formal sector. However, it must be noted that the distinction between formal and informal sector is becoming blurred as the formal sector is now characterised by casual, temporary and insecure jobs. The informal sector is mainly dominated by small to medium enterprises which offer insecure and unstable jobs. Overall 22 out of 58 migrants were employed in the informal sector while even those employed in the 'formal' sector experienced insecurity of tenure, low wages and thus were in precarious positions. Most jobs were contract-based lacking any social insurance. Migrants' jobs were characterised by long working hours (more than 8 hours) and low earnings. The following table shows estimates provided by migrants regarding their monthly earnings. 
Table 1: Earnings per month

\begin{tabular}{|c|c|c|c|}
\hline Earnings per month & Frequency & Percent & $\begin{array}{c}\text { Cumulative } \\
\text { Percent }\end{array}$ \\
\hline None & 4 & $6.9 \%$ & $6.9 \%$ \\
\hline Less than R1500 & 7 & $12.1 \%$ & $19 \%$ \\
\hline Between R1500 and R3000 & 16 & $27.6 \%$ & $46.6 \%$ \\
\hline Between R3001 and R6000 & 13 & $22.4 \%$ & $69 \%$ \\
\hline Between R6001 and R10 000 & 6 & $10.3 \%$ & $79.3 \%$ \\
\hline Above R10 000 but less than R15000 & 6 & $10.3 \%$ & $89.7 \%$ \\
\hline Above R15 000 & 6 & $10.3 \%$ & $100 \%$ \\
\hline Total & 58 & $100 \%$ & \\
\hline
\end{tabular}

Source: author's own representation

Migrants did not earn much per month. Sixty-nine percent (69\%) of the migrants took home less than R 6000 (which was about USD\$600 using an exchange rate of 1USD is equivalent to $10 \mathrm{ZAR}$ ) per month while the rest (31\%) earn more than R6000. Almost half of the migrants studied (47\%) earned less than R3000 (about USD\$300). They were barely surviving since these same individuals would pay rent of about R600 per month for a single room and spend almost the same amount in transport costs, the remainder would be utilised for food and other costs relating to the sustenance of the workers. In order to cut costs some migrants preferred shared accommodation with friends and relatives. This co-residential strategy was also common among the Senegambian migrants in Belgium (Van Nieuwenhuyze, 2009).

\section{Migrants' perceptions on why employers chose them over other groups}

There were positive and negative reasons given by Zimbabweans as to why employers preferred them over other groups of workers, especially the local South African workers. The common arguments put forward by participants were that employers preferred Zimbabwean migrants because; they were hard-working, intelligent, could speak fluent English, respectful and they maintained consistency in terms of coming to work and executing their tasks. Zimbabweans portrayed local South African workers as unreliable workers who, after receiving their salaries, would not report for duty consistently. The participants further highlighted that some local South Africans tended to be vocal when it came to their rights and benefits at work, creating 'trouble' at work. The earlier discussion of the views by Waldinger and Lichter (2003) indicated how employers dislike workers who are 'combative' and seem not to 'know their place'. In comparison, Zimbabwean employees thought employers perceived them as generally quiet, contented and unlikely to cause trouble by complaining. The migrants were aware of the exploitation and abuse they suffered at the hands of employers but they seemed to have less choice because of their devalued status as 'foreigners'. That is why some ended 
up using fake identity books so that they could pass off as South African and become eligible for certain benefits and rights at work available to locals.

Migrants also argued that among the characteristics that gave them a competitive advantage over locals were: their hard-work and eagerness to learn and adapt quickly. They argued that these tended to be valuable characteristics that Zimbabweans were praised for among all migrant groups. Scott narrated how he expressed his zeal to learn on the job:

"After two weeks the white man asked if I could use machines. I agreed and started using a grinder for the first time. I did it for a week and he called me again and asked if I could use a cutter and I told him I will read the instructions and use it. He tested me for two hours and saw that I was able. He was satisfied and then made me the operator of the machine. Other local colleagues got jealous and started asking why the machine was given to a newcomer after only three weeks. They knew I was foreign because I used my real Zimbabwean name".

This willingness to learn on the job was a tenet shared by both men and women. Karen explained how she was the envy of her colleagues when she became the favourite employee because of her ability to operate a machine:

"I was working at a Fish and Chips outlet and I showed my ability to clean a washer which was believed to be a man's job. So I was able to clean it in the absence of male employees and the employer was happy. Nobody had taught me to do it".

In her previous employment, Karen had also managed to excel in a guesthouse (bed and breakfast facility) where she worked as a maid. She had not done that job before but she distinguished herself to the extent that she was given a permanent post. She had started as a temporary worker who was holding fort for someone on maternity leave. She was now constantly being referred to other jobs by her former employer because of her good conduct.

The willingness to learn was also shown in the need to improve oneself through acquisition of diplomas and certificates in various fields. Bernard explained:

"When I did a driving course some of my folks laughed at me saying: whose car will you drive? Where will you drive it in South Africa? Why drive a car when you don't have a house? But this became my advantage over others. When there was a post that required a security guard with his own gun and a drivers' licence, that became my opportunity and I was appointed supervisor. I upgraded myself by taking courses in supervision, management and administration". 
This was mainly the case with documented migrants, especially those that had acquired work permits and South African identity books. Among the participants, there were a few migrants pursuing degrees through open distance learning while the majority had acquired diplomas and certificates in various fields. Acquisition of a South African academic qualification was viewed as an added advantage when looking for a job because migrants would not have to endure the hassles of qualifications evaluation by the South African Qualifications Authority (SAQA). Even those migrants who had acquired degrees in Zimbabwe felt the need to add certificates and diplomas acquired from South African institutions.

The majority of migrants (76\%) stated that employers preferred Zimbabweans because they worked harder than South Africans and were willing to experiment with machines and new methods of doing work. Participants provided negative stereotypical perceptions of local South Africans as lazy, uneducated and unwilling to learn. They used these stereotypes as reasons why employers preferred foreign workers. Tapera had this to say:

"South Africans are lazy. If foreigners go on leave the employer has a problem. You see the boss hugging a Zimbabwean when he comes back from leave, this shows Zimbabweans know their jobs. If it is a local South African coming back from leave the boss is not bothered...so when they get paid they do not come to work next Monday... They drink a lot".

Migrants generally insinuated that Zimbabweans had a work ethic that was different from South Africans. This work ethic entailed hard-work, dedication and reliability. This perception exaggerated the qualities of Zimbabwean migrants. Migrants under study also believed that their fluency in the English language was far much better than local black South Africans. They generally believed that they were also more educated than South Africans. Vivienne expressed this point clearly when she said:

"I believe that coming here to South Africa was an advantage for me because a lot of people couldn't speak proper English... so if you are a waitress you must be able to communicate with customers. In Zimbabwe we were taught English... even today Zimbabweans have an advantage when it comes to speaking English. It was not difficult for any manager to hire me. I would go there and speak my (her emphasis) English which was far much better than (that of) any South African”.

Mosala (2008) agrees that Zimbabweans have in some sectors gained an advantage over locals because of their command of the English language. However, that better command of English sometimes landed Zimbabweans in trouble with locals who could easily tell that one was Zimbabwean because of the accent. Vivienne further explained: 
"[...] but that also became a disadvantage because if you were able to speak English well the locals would start asking; where do you come from?, while you are serving them and then you become afraid to tell them that you are from Zimbabwe because of the negative reaction you will receive $[\ldots]$ ”.

Research participants believed that the preference for Zimbabwean migrants above all other groups was also because they could be exploited easily by employers without them suffering any financial and legal consequences. This was linked to the images and information that was conveyed by the mass media which portrayed Zimbabweans as desperate and willing to do anything for low wages. The images portrayed conveyed the message of a fortress South Africa that Zimbabweans desperately wanted to enter. Morgan expressed the following sentiments:

“[...] we don't have as many opportunities as locals. Foreigners are perceived as desperate. They see films of desperate foreigners jumping the fence and think we are desperate... The employer can sack you at any time thinking you are not going to take action and it's mostly true".

Farai also argued:

"We are desperate and stranded. They prefer us and at the same time mistreat us because they think we are so desperate".

The willingness of Zimbabweans to accept any job and impress employers was, on its own, dangerous, because regulations could be ignored and flouted to the benefit of the employer. This meant that Zimbabwean workers could be exposed to dangerous working conditions endangering their health in the process of securing employment. A good example was my key informant Tatenda, who worked as a waitress at a food outlet. Almost every day she had nosebleeds which she attributed to chemicals they used to clean the cooking space. However, she has no better option but to continue enduring these as the other option of leaving the employer and finding another job, was a mammoth task for a migrant using an Asylum Seeker's permit. The employer pointed out to her that she would not receive any assistance from the organisation in addressing her regular nose-bleeding. She was told to "either take it or leave it" and she preferred to "take it". Since there were many Zimbabweans in her position, it can be assumed that many rationalised to keep such jobs than risk unemployment. This situation renders support to Sassen-Koob's (1985) assertion that the willingness to staff these undesirable jobs created a constantly suitable source of labour for employers.

Zimbabweans also argued that they had limited choices because good jobs were out of their reach, reserved for locals. These migrants reasoned that they had to make good with the "bad' jobs available to them. For those that were lucky to have found better jobs, migrants perceived that they were side-lined or considered last for promotion. The following sentiments were expressed: 
"Some jobs are reserved for South African locals. They don't want foreigners, for example, I discovered that they wanted drivers in Pretoria. I went there but we were told they don't want Zimbabweans" (Edgar).

"I attended and passed an interview at Tembisa hospital but they said that they were told not to employ Zimbabwean nurses and doctors... They said if I had a South African ID they would take me" (Hillary - a qualified nurse).

“[...] currently I feel I deserve a managerial position but I don't have it simply because I am a foreigner, yet I have achieved the educational levels required for management...For some jobs, it is out-rightly written that foreigners should not apply... even if you qualify, for example in financial management and accounting. In some websites when you register for employment they ask for a South African identity book and if you don't have but you possess a work permit the minute you write passport and permit then you don't get a response... In some cases it's stated that in this job we are not considering anyone with a work permit" (Trish).

"They preferred South Africans there. I was the only Zimbabwean and I worked as a receptionist... I would be the last to get paid. They would say they forgot to pay me. They would start by paying whites, then local blacks and then me. If I didn't ask I would not get paid" (Hillary).

High skilled migrants reported social exclusion in the form of blocked opportunities for career growth. Migrants alluded to the Broad Based Black Economic Empowerment (BBBEE) Act of 2003 which encouraged employers to promote blacks (South African citizens) into management positions. However, what migrants were experiencing could also have been the implementation of the Employment Equity Act of 1998 which advocates for affirmative action towards historically disadvantaged groups, defined as designated groups, which are the blacks, women and the disabled South African citizens.

"Government policies are quite clear. They are encouraging South Africans to take managerial posts. Employers love Zimbabweans but government policies are constraining. They give you permits but they change policies in the workplace, you end up without a job. Now they want to employ people with permanent residence and citizenship" (Barbara).

The above quotation from Barbara reveals how migrants also perceived the government as shifting goal posts - where migrants with work permits could not access employment. 


\section{Sectors dominated by Zimbabwean migrants}

Migrants gained entry into private organisations that did not strictly require identity documents. These organisations provided access to employment to migrants using Asylum Seeker's permits. Migrants who did have any permits still found employment in these private companies where both entry and exit tended to be easy. In some cases, there were interviews that migrants attended (especially waitresses) which they passed easily after being coached by their relatives who would have found them these jobs in the first place. In other cases, there are no interviews, the curriculum vitae was adequate to get one employed.

Table 2: Current Job of Participant

\begin{tabular}{|c|c|c|}
\hline Job & Frequency & Percent \\
\hline Food service & 9 & $16 \%$ \\
\hline Welding & 2 & $3 \%$ \\
\hline Driving/transport industry & 8 & $14 \%$ \\
\hline Hairdressing & 3 & $5 \%$ \\
\hline Domestic & 4 & $7 \%$ \\
\hline Unemployed & 4 & $7 \%$ \\
\hline Retail & 4 & $7 \%$ \\
\hline Construction & 1 & $2 \%$ \\
\hline Security & 3 & $5 \%$ \\
\hline Teaching & 3 & $5 \%$ \\
\hline Training & 1 & $2 \%$ \\
\hline Accounts and finance & 2 & $3 \%$ \\
\hline IT and computers & 8 & $14 \%$ \\
\hline Other & 6 & $10 \%$ \\
\hline Total & 58 & $100 \%$ \\
\hline
\end{tabular}

Source: author's own representation

Females dominated in domestic services (as domestic workers), hairdressing and hospitality industry (as waitresses), teaching and training, while males were predominantly found in the hospitality (as waiters and drivers), information technology and computers, motor mechanics, transport and security industries. Recruitment via referrals allowed the employers to avoid costs of recruitment and selection because the employees were careful enough to refer migrants of 'good standing' to their employers. The table below shows the various areas of employment for Zimbabweans. These areas tended to be mainly in the low end and a few in the high end service sector such as waitressing, driving, domestic services and information technology. 
While migrants could switch jobs and positions, they rarely moved out of their industry sector. The table below shows the jobs that migrants did when they first arrived in Johannesburg. It is clear that these were still the same sectors receptive to migrants. However, there were clear cases of upward movement where one moved from domestic work to office work. This shift tended to be facilitated by sympathetic/paternalistic employers. This was certainly true for female migrants with recognised professional qualifications such as a Diploma in teaching, who started off as domestic maids. The same argument could be made for former employers of self-employed migrants who facilitated migrants' acquisition of human and social capital. Such employers defied the stereotype that employers exploited their migrant workers.

Table 3: The First Job of Participant

\begin{tabular}{|c|c|c|}
\hline First Job & Frequency & Percent \\
\hline Construction & 10 & $17 \%$ \\
\hline Domestic & 11 & $19 \%$ \\
\hline Security & 5 & $9 \%$ \\
\hline Hairdressing & 4 & $67 \%$ \\
\hline Office & 8 & $14 \%$ \\
\hline Other & 13 & $22 \%$ \\
\hline Waitressing & 7 & $12 \%$ \\
\hline Total & 58 & $100 \%$ \\
\hline
\end{tabular}

Source: author's own representation

Most men started by working in the construction and security industries as well as office work, while most women started in the domestic, office, waitressing and hairdressing sectors. The category of 'other' includes jobs in the retail, motor mechanics and service industries. Migrants worked as drivers, motor mechanics, graphic designers, engineers, teachers and sales agents.

\section{Rights and benefits at work}

There were generally few or no workers' rights for most Zimbabwean migrants. The worst areas were security and waitressing where migrants endured long working hours that were not considered in the calculation of wages. Workers worked up to 12 hours a day but still got less than R2000 per month with one day off per week. They usually knocked off well into the night (between $11 \mathrm{pm}$ and $3 \mathrm{am}$ ). In some cases transport was not provided (thus making it dangerous to travel at night) and contracts were verbal agreements. While this situation also affected locals who were in the same industry, it was serious for migrants who were the majority in these sectors, which in any case, tended to be shunned by locals. 
A worker could be dismissed without notice in the same way that he/she could also disappear without notice. Absence for more than two days was interpreted as loss of interest in the job and the worker was easily replaced. This is what happened with Pauline when she went to process her Asylum seeker's documents for two days. She found that her employer had replaced her with another domestic worker.

Most Zimbabwean migrants did not belong to any worker associations. They shunned union activities. While the Immigration Act of 2002 (as amended in 2004) states that it is up to the employer to ensure that migrant workers with permits received fair salaries and enjoyed the same rights as their local counterparts, employers usually did not bother. Since enforcement was left to employers, there were chances of exploitation of migrant workers. Furthermore, ignorance, combined with "reluctance to cause trouble" caused migrants to accept unfair situations. That is why Alex argued that "foreigners have no rights. The moment you express yourself you expose yourself".

The type of contracts migrants got tended to be tied to their legal status. Those whose presence in the country was deemed illegal or used Asylum Seeker's permits tended to have verbal contracts, while those whose stay was legal or who had acquired South African documents, had formal written contracts and got payslips. On verbal contracts, Scott describes how he was engaged:

"When I first joined the job I did not know whether it was permanent or not. I just heard workmates saying they would be working with me permanently. I never signed any contract... But my white boss showed interest in me".

Norbert also started the same way:

"When I started (in 2009) I just worked for months without signing a contract even though I knew I was entitled to one. I could not ask for fear of jeopardising my job. The employer formalised the situation and gave me contract this year (2012)."

Norbert signed a contract in 2012 after almost four years of not knowing how long he was going to be at that organisation. This was also complicated by the fact that he was employed as an Asylum Seeker's permit holder. He only got a general work permit in 2010. The problem of a verbal agreement is that it is not binding and enforceable. In Scott's case there was no agreement at all. Scott had been brought by his brother to the job and negotiations had been done on his behalf, by the brother. Unfortunately, he did not last at the job as he was sacked at the end of the month for lack of identity documents after locals had complained of favouritism on the part of the employer.

Paradzayi had this to say about his experiences prior to acquiring a passport and a general work permit: 
"I used to work for a South African white man. After I told him the truth that I am a Zimbabwean he would shout at me saying you are Zimbabwean and you don't have identity papers, I can call home affairs people any time. He always did this at month-ends, so every time I lived in fear of being deported...”.

Morgan also had this to say:

"The employer can sack you anytime thinking you are not going to take any action and it's mostly true. People don't fight, unlike the locals who are very union conscious. I have a cousin who is working 18 hours a day in a restaurant. There is no (payment for) over-time. Last month, he was paid R500. I told him to record all the hours he had worked so that the day he is fired he can demand his money... he uses an Asylum Seekers permit".

Desperation made undocumented Zimbabwean migrants to accept almost any kind of contract and endure quietly. While they were aware of exploitation and abuse they had no better choice than to accept the terms and consider themselves lucky to have the jobs in the first place. They only changed jobs or became vocal about their conditions once their status was legalised. Those who were documented, found that their educational qualifications did not matter as they occupied low status, unskilled jobs. That is why many Zimbabweans in South Africa argued that education does not really matter (Maphosa, 2010).

Whether documented or undocumented, Zimbabweans largely did not participate in union activities. This was either out of "not wanting to create trouble" or because they were simply ignored. For example, Ruth had a passport and work permit but she was not a member of the union at her workplace. She said every time there were union meetings at her workplace, Zimbabweans were left outside. They were only told afterwards what transpired at the meetings. It is possible that Ruth did not actively seek participation and therefore waiting to be invited was simply an excuse for unwillingness to participate.

There were cases of migrants who were lucky to work in organisations that were dominated by migrants to the extent that they could enforce their rights informally, even though these rights were not written down. This was facilitated by their influence in middle management that was dominated by Zimbabweans. Kevin explained that:

"We have rights here. Our managers are Zimbabwean.... (and) the South Africans cannot complain against us because all the management is Shona".

The clustering of Zimbabweans in this particular trucking company shielded them from discrimination by locals and actually threatened the locals who were the minority in this organisation. In such situations, locals were afraid to express themselves and could not be xenophobic for lack of support from management. Lower level migrant employees 
(the truck drivers and mechanics) could enforce informal norms on their Shona managers by reminding them that they come from the same country. In a related case, Norbert explained how Zimbabweans dominated a steel and engineering department of a company to the extent that they felt safe from local competition:

"South Africans have no option but to like us since our department is very powerful. We earn more money than them and recruit each other as Zimbabweans".

Karen also explained how they related with the Pedi woman they worked with at her workplace where she was employed as a tailor:

"[...] the white woman says she wants Zimbabweans only. There are four (three Shona and one Ndebele, [Karen]) Zimbabweans and one South African. The Shona women and I are united. We understand each other. The Pedi woman doesn't like us".

All the cases narrated above reveal how migrants could enforce certain norms (even when they are not written down) by virtue of being a majority in a department and also by having some level of support from management.

In terms of benefits available on the job it was clear that the majority of migrant workers $(60 \%)$ had nothing offered to them except their monthly salary. Most benefits depended on contributions by members and because migrants did not contribute to social insurance, they could not expect to benefit either. In the absence of medical insurance, protection from injury and pension this meant that when migrants got sick they forked out their own money and upon injury or death there was no compensation. The following table displays this information.

\section{Table 4: Benefits Available at Work}

\begin{tabular}{|c|c|c|}
\hline Benefits at work & Frequency & Percent \\
\hline Funeral fund & 5 & $9 \%$ \\
\hline All benefits are there & 2 & $3 \%$ \\
\hline None & 35 & $60 \%$ \\
\hline Not applicable & 11 & $19 \%$ \\
\hline UIF & 5 & $9 \%$ \\
\hline Total & 58 & $100 \%$ \\
\hline
\end{tabular}

Source: author's own representation

A few individuals (9\%) stated that they contributed to the Unemployment Insurance Fund (UIF) which would cushion them in case they lost their jobs. There were two individuals who stated that they have all benefits including UIF, medical aid and 
funeral fund. These individuals were among those that had gone through the naturalisation process and were now viewed as citizens in South Africa. They had parents who were already in South Africa. Sections 26 and 27 of the application for permanent residence permit allows for a child (without age restriction) of a South African citizen or a relative 'within the first step of kinship' to apply for permanent residency and naturalisation.

The category labelled 'not applicable' reflects those that were either unemployed or selfemployed. It was worrisome that the self-employed could not afford to pay for their own social insurance. But even among those that could afford to pay (e.g. the security company owner and training company owner) migrants thought that having medical insurance was a waste of money, preferring to pay cash whenever medical attention was needed.

\section{Conclusions}

This paper chronicles the lives of Zimbabwean migrants in the South African labour market based on an in-depth study of fifty eight migrants, showing their experiences and perceptions of these experiences. As they compared their country of origin and South Africa, Zimbabweans perceived that South Africa had better and more opportunities for work and survival. Clearly Zimbabweans thought that they were far much desirable to the employers than the South African locals. They were, however, not naive to the fact that the employer preferences were based not on 'good' intentions but on the willingness to exploit the disadvantaged state of the migrants.

However, in the process some migrants fared very well and actually managed to create enclaves for their migrant group which monopolised certain industry sectors. A few Zimbabweans experienced upward social mobility while others managed just to get by and not necessarily get ahead. Whether in the formal or informal sector, almost all migrants experience varying levels of precariousness, including those that have ventured into self-employment. It is critical to note that Zimbabwean migrants were confronted with many challenges that largely stemmed from their migrant status which was devalued on the labour market. This factor, combined with others such as low skills, employer interests, race and poverty, exposed Zimbabweans to precarity on the South African labour market in a much defined manner as has been discussed in this paper. It is recommended that the South African government recognises the pivotal role played by migrants and define the minimum standards of work for documented migrants. The Zimbabwean government should begin to take a keen interest in the welfare of its citizens by engaging in bilateral agreements with destination countries such as South Africa and Botswana. Instead of looking at migrants as traitors or sell-outs, migrants could be perceived as a conduit for remittances that could assist rebuild the Zimbabwean economy. The new government of Emmerson Mnangagwa has chanted a 
slogan that "Zimbabwe is open for business" and Mnangagwa himself has visited migrants in selected African, Asian and European countries. It remains to be seen whether there are clear, genuine moves to improve the situation of Zimbabwean migrant workers in these countries. For now, the majority of Zimbabweans survive as the 'precariat' in the South African labour market, and as long as the Zimbabwean economic and political situation is not improved, Zimbabweans will continue making comparisons and rationalising that the South African labour market is better.

\section{References}

Betts, A., \& Kaytaz, E. (2009). National and International responses to the Zimbabwean exodus: Implications for the refugee protection regime. Geneva: UNHCR, New Issues in Refugee Research, Research Paper Number 175.

Bloch, A. (2008). Gaps in protection: undocumented Zimbabwean migrants in South Africa. Migration Studies Working Paper Series, 38, 1-19, Forced Migration Studies Programme, Johannesburg: University of Witwatersrand.

Bolt, M. (2015). Zimbabwe's migrants and South Africa' border farms: the roots of impermanence. Cambridge: Cambridge University Press.

Borjas, G.J., \& Tienda M. (eds.) (1985). Hispanics in the US Economy. Orlando: Academic Press.

Browne, K., (2005). Snowball sampling: using social networks to research non heterosexual women. International Journal of Social Research Methodology, 8(1): 47-60. DOI: https://doi.org/10/ 1080/1364557032000081663.

Browning, H.L., \& Rodriguez, N. (1985). The migration of Mexican indocumentados as a settlement process: implications for work. In: Borjas, G.J., and Tienda, M. (Eds.): Hispanics in the US Economy. Orlando: Academic Press (pp. 277-297).

Castles, S. (2002). Migration and community formation under conditions of globalisation. International Migration Review, 36(4), 1143-1168.

Castles, S., \& Miller, M.J. (2009). The age of migration: international population movements in the modern world (4 $4^{\text {th }}$ Edition). Hampshire: Palgrave MacMillan.

Cholewinski, R. (2005). Study on obstacles to effective access of irregular migrants to minimum social rights. Strasbourg: Council of Europe, F-67075.

Crush, J., \& Tawodzera, G. (2011). Medical xenophobia: Zimbabwean access to health services in South Africa. Cape Town: SAMP and OSISA. Migration Policy Report Number 54.

Crush, J., \& Tevera, D. (2010). "Exiting Zimbabwe”. In: Crush, J., Tevera, D. (Eds.): Zimbabwe’s Exodus: Crisis, Migration and Survival. Ottawa: SAMP, in cooperation with IDRC (pp. 1-51).

Crush, J., Williams, V., \& Nicholson, P. (2009). Migrants' rights after apartheid: South African response to ICRMW. In: De Guchteneire, P., Peccoud, A., Cholewinski, R. (Eds.): Migration and human rights, the United Nations convention on migrant workers' rights. Cambridge: CUP \& UNESCO (pp. 248-277).

De Guchteneire, P., Peccoud, A \& Cholewinski, R. (Eds.) (2009). Introduction: the UN convention on migrant workers' rights. In: De Guchteneire, P., Peccoud, A., Cholewinski, R. (Eds.): 
Migration and human rights, the United Nations convention on migrant workers' rights. Cambridge: CUP \& UNESCO (pp. 1-46).

Dumba, S., \& Chirisa, I. (2010). The plight of illegal migrants in South Africa: A case study of Zimbabweans in Soshanguve extension 4 and 5. International Journal of Politics and Good Governance, 1(1.2), 1-20.

Figart, D.M., \&Warnecke, T.L. (Eds.) (2013). Handbook of research on gender and economic life. Cheltenham: Edward Elgar.

Human Rights Watch. 2006. Unprotected migrants: Zimbabweans in South Africa's Limpopo Province. July 2006: 18(6), Washington: HRW.

Hungwe, C. (2014). Zimbabwean migrant entrepreneurs in Kempton park and Tembisa, Johannesburg: challenges and opportunities. Journal of Enterprising Culture, 22(3), 349-373.

Hungwe, C., \& Gelderblom, D. (2014). Understanding the social exclusion of Zimbabwean migrants in Johannesburg, South Africa. Journal of Community Positive Practices, XIV(1), 75-91.

International Labour Organisation (ILO), 2011. From precarious work to decent work: Policies and regulations to combat precarious employment. Geneva: ILO.

Immigration Act Number 13 of 2002, Available at: http://www.infor.gov.za/gazette/acts/2002/a1302.pdf.

Immigration Amendment Act Number 19 of 2004, Available at http://www.infor.gov.za/acts/ 2004/a19-04.pdf.

Kalleberg, A. L. (2009). Precarious work, insecure workers: Employment relations in transition. American Sociological Review, 74(1), 1-22.

Kalleberg, A. L. (2013). Good jobs, Bad jobs. New York: Russell Sage Foundation.

Maphosa, F. (2010). Transnationalism and undocumented migration between rural Zimbabwe and South Africa. In: Crush, J., Tevera, D. (Eds.): Zimbabwe's exodus: crisis, migration and survival. Ottawa: SAMP in cooperation with IDRC (pp. 345-362).

McGregor, J. (2010). Introduction: the making of Zimbabwe's new Diaspora. In: McGregor, J., Primorac, R. (Eds.): Zimbabwe's new Diaspora: displacement and the politics of survival, New York: Berghahn Books (pp. 1-36).

Mosala, S.M.G. (2008). The work experience of Zimbabwean migrants in South Africa. Harare: ILO Sub Regional Office for Southern Africa.

Peccoud, D. (Ed.) (2004). Philosophical and spiritual perspectives on decent work. Geneva: ILO.

Prada, E.M. (2013). Economic development and migration in European Union. Ovidius University Annals, Economic Sciences Series, 13(1), 259-264.

Rutherford, B. (2010). Zimbabweans on the farms of Northern South Africa. In: Crush, J., Tevera, D. (Eds.): Zimbabwe's exodus: crisis, migration and survival. Ottawa: SAMP in cooperation with IDRC (pp. 244-268).

Sassen-Koob, S. (1985). Changing composition and labour market location of Hispanic immigrants in New York city 1960-1980. In: Borjas, G.J., and Tienda, M. (Eds.): Hispanics in the US Economy. Orlando: Academic Press (pp. 299-322).

Standing, G. (2011). The Precariat. London: Bloomsbury.

Tucker, D. (2002). Precarious non-standard employment-A review of literature. Labour Market Policy Group, Department of Labour, Wellington. 
76 Hanging in there: Zimbabwean migrant workers in Johannesburg

UN Department of Economic and Social Affairs (UNDESA) Population Division (2016). International Migration Report 2015 (ST/ESA/SER.A 384).

Van Nieuwenhuyze, I. (2009). Getting by in Europe's urban labour markets: Senegambian migrants' strategies for survival, documentation and mobility. Amsterdam: Amsterdam University Press.

Vigneswaran, D., Araia, T., Hoag, C., \& Tshabalala, X. (2010). Criminality or monopoly? Informal immigration enforcement in South Africa. Journal of African Studies, 36(2), 465-517.

Waldinger, R., \& Lichter, M.I. (2003). How the other half works: Immigration and the social organisation of labour. Berkeley: University of California Press.

Young, M.C. (2010). Gender differences in precarious work settings. Industrial Relations, 65(1), 74-97. 